\title{
Landfill Sites Selection Using Analytical Hierarchy Process and Ratio Scale Weighting: Case Study of Al-Mahawil, Babylon, Iraq
}

\author{
Ali Jalil Chabuk', Nadhir Al-Ansari'1, Hussain Musa Hussain'², Sven Knutsson'1, Roland Pusch1 \\ ${ }^{1}$ Department of Civil Environmental and Natural Resources Engineering, Lulea University of Technology, Lulea, Sweden \\ ${ }^{2}$ Department of Geology, Faculty of Science, University of Kufa, Kufa, Iraq \\ Email: ali.chabuk@ltu.se,nadhir.alansari@ltu.se,humhudhy02@gmail.com,Sven.Knutsson@ltu.se,drawrite.se@gmail.com
}

How to cite this paper: Chabuk, A.J., Al-Ansari, N., Hussain, H.M., Knutsson, S. and Pusch, R. (2017) Landfill Sites Selection Using Analytical Hierarchy Process and Ratio Scale Weighting: Case Study of Al-Mahawil, Babylon, Iraq. Engineering, 9, 123-141.

https://doi.org/10.4236/eng.2017.92006

Received: January 10, 2017

Accepted: February 13, 2017

Published: February 16, 2017

Copyright $\odot 2017$ by authors and Scientific Research Publishing Inc. This work is licensed under the Creative Commons Attribution International License (CC BY 4.0).

http://creativecommons.org/licenses/by/4.0/

\begin{abstract}
Selecting a landfill site is an optimal solution for the disposal of solid waste in Al-Mahawil Qadhaa, both to fulfill the environmental and scientific requirements, and to comply with regulations and restrictions in this Qadhaa. Presently, there is no landfill site in the area that meets the scientific site selection criteria. Therefore, in this study, two methods of multi-criteria decision-making and Geographic Information System (GIS) were used to produce a map of candidate sites for landfill. Fifteen criteria were entered within GIS: groundwater depth, rivers, soil types; agriculture lands use, land use, elevation, slope, gas pipelines, oil pipelines, power lines, roads, railways, urban centers, villages and archaeological sites. The Analytical Hierarchy Process (AHP) is the first method that was applied to derive criteria weightings using the matrix of pairwise comparisons. The second method was the Ratio Scale Weighting (RSW), which is based on experts' opinion, in order to identify the criteria weightings by giving a ratio score value for each criterion relative to the other criteria. Accuracy assessment (Kappa and Overall Assessment) methods were used to compare the two raster maps which resulted from the two models, and to determine the percentage value of matching pixels for the two maps. Two suitable candidate sites for landfill were identified that satisfy the requirements with an area of $2.218 \mathrm{~km}^{2}-2.950 \mathrm{~km}^{2}$ in order to accommodate the solid waste generated from the Qadhaa in the period 2020 to 2030.
\end{abstract}

\section{Keywords}

Accuracy Assessment Methods, Landfill, (AHP) Method, (RSW) Method, GIS, Al-Mahawil Qadhaa 


\section{Introduction}

The term "Municipal solid waste" (MSW) is used for waste that is produced in urban areas, and which is not uniform in characteristics or content. The properties and quantity of generated waste in a region are based on the lifestyle of inhabitants in the region, the standard of living, increasing levels of commercial and industrial activities, as well as the type and quantity of the natural resources in a region. The major components of urban waste are often divided into two types: organic and inorganic [1]. Solid Waste Management includes many processes such as the incineration and burial of waste in landfills, recycling, reducing quantities of waste, and re-using [2]. Landfill sites are considered necessary to manage waste, even if other techniques of waste management are adopted. In countries that burn their waste, a suitable landfill site to dispose of the resulting ashes from burning is still required [3] [4]. The process of landfill siting is subject to several factors, including public health concerns, growing environmental awareness, government regulation, government and municipal funding, increasing political and social opposition to the establishment of landfill sites, and reduced land availability for landfills. Therefore, this process is considered to be one of the most complex tasks for planners and authorities [5].

Presently, there is no landfill site in Mahawil Qadhaa that meets the relevant scientific and environmental criteria used in developed countries. There are only four waste disposal sites distributed throughout the cities of the Qadhaa [6]. Therefore, the integration of GIS and multi-criteria decision making methods were used to solve the problem of landfill siting in Mahawil Qadhaa, Babylon, Iraq. GIS has a high ability to manage large volumes of spatial data from a variety of sources. Consequently, GIS plays a significance role in contributing to the selection of a landfill site [7] [8] [9].

In this study, two types of methods of multi-criteria decision making were used: The Analytic Hierarchy Process (AHP) method, and the Ratio Scale Weighting method. The AHP is one of the most common decision making methods, with a high ability to solve complex problems in different fields [10] [11]. AHP was developed by [10], and it is used to determine the consistency of weightings for criteria through constructing a matrix of pair-wise comparisons. In the literature, many candidate sites have been identified among several potential landfill sites using GIS and AHP (e.g. [12]-[18]). In the Ratio Scale Weighting method, the weightings of criteria were given in the direct way based on the opinion of experts, a literature review and the relative importance of each criterion to others. [19] [20] [21] implemented the Ratio Scale Weighting method with GIS in their research to produce the criteria weightings in the solving the problem of sites selection for landfill.

The accuracy assessment method is used in this study to make a comparison between two raster maps that were produced using the AHP and RSW methods. Accuracy assessment methods (Kappa and Overall Assessment) were used to evaluate the output images and measure the correlation between the two input image classifications from the two models. The Kappa technique was developed 
by [22].

This study seeks to select suitable sites for landfill that fulfill the scientific and environmental criteria in Al-Mahawil Qadhaa, Iraq, by using the Analytic Hierarchy Process (AHP and RSW) methods within a GIS environment. Appling the accuracy assessment (Kappa and Overall Assessment) method was done in order to compare the output raster maps that resulted from multi-criteria decision making models.

\section{Study Area}

Al-Mahawil Qadhaa consists of the four cities of Al-Mahawil, which is considered to be the administrative center of Al-Mahawil Qadhaa, Al-Neel, Al-Mashroa, and Al-Imam. Al-Mahawil Qadhaa is located in the northern part of the Babylon Governorate, where this Qadhaa connects the Babylon Governorate via many roads with the Iraqi capital, Baghdad. It is situated between longitude $44^{\circ} 18^{\prime} 15^{\prime \prime} \mathrm{E}$ and $45^{\circ} 2^{\prime} 7 \mathrm{~F}$, and latitude $32^{\circ} 50^{\prime} 8^{\prime \prime} \mathrm{N}$ and $32^{\circ} 25^{\prime} 52^{\prime \prime} \mathrm{N}$ (Figure 1).

The area of Al-Mahawil Qadhaa is $1716 \mathrm{~km}^{2}$, which constitutes $32.3 \%$ of the total area of the Babylon Governorate [23]. The population of Al-Mahawil Qadhaa was 356,550 in 2015, according to the statistics of the [24]. This figure represents $17.02 \%$ of the total population in the governorate. The proportion of rural population in Al-Mahawil Qadhaa was 77.4\% in 2015, which constituted the highest percentage when compared with the other cities in the Babylon Governorate.

\section{Determination of Sailable Criteria}

In each study area, there are many criteria and factors should be taken into consideration when selecting suitable sites for landfill to meet the established scientific

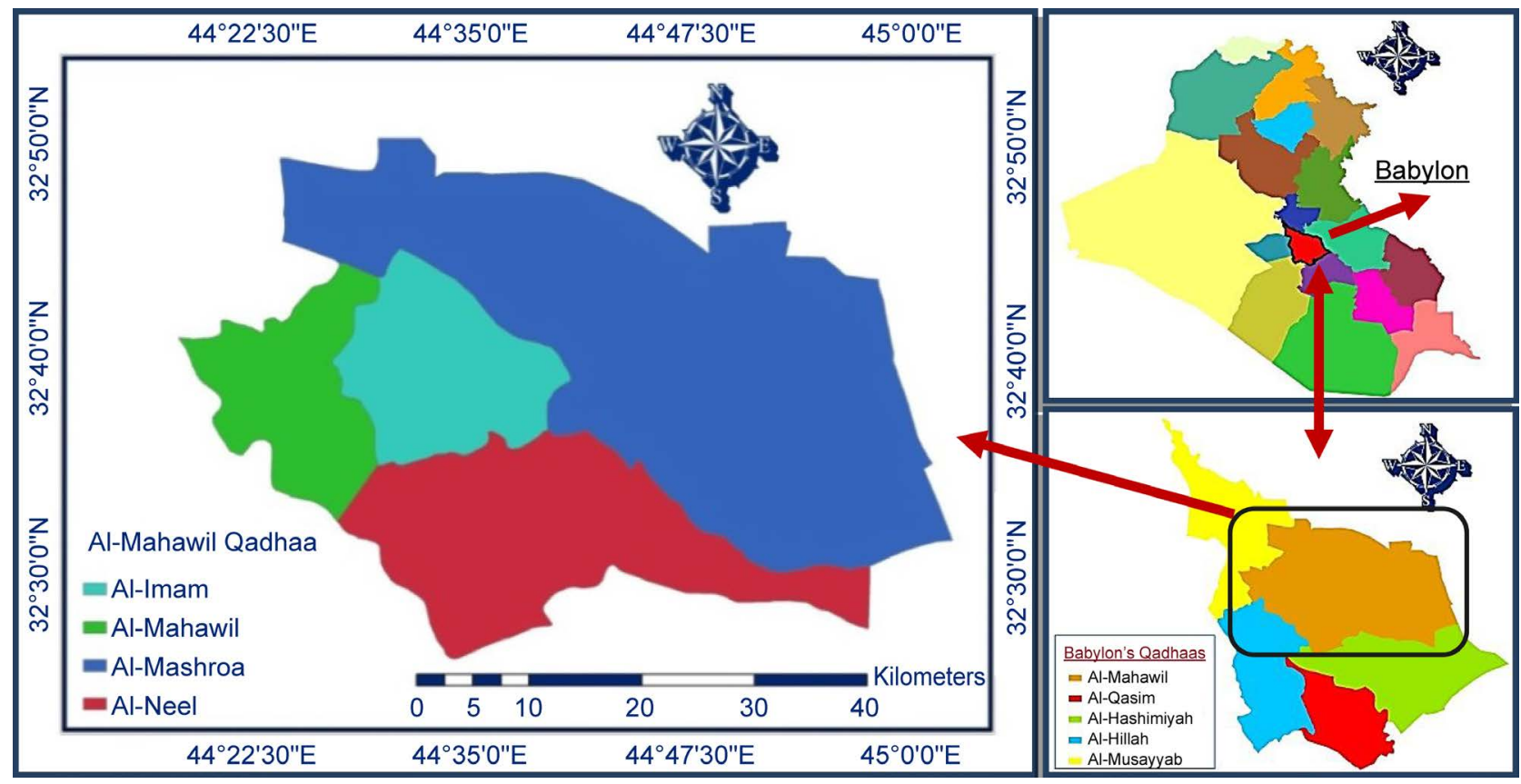

Figure 1. Study area of the Al-Mahawil Qadhaa. 
and environmental criteria based on previous studies in this field, expert's opinions and available data about the study area. Fifteen of criteria were selected from different sources. These criteria used are groundwater depth, rivers, soil types, agriculture lands use, land use, elevation, slope, gas pipelines, oil pipelines, power lines, roads, railways, urban centers, villages and archaeological sites.

\section{Preparing the Required Maps}

Many steps were implemented within the GIS in order to produce the final required layers as raster maps in this study using special analysis tools (e.g. Buffer, Clip, Extract, Overlay, Proximity, Convert, Reclassify and Map Algebra, etc.). Many sources were used to prepare the raster maps within GIS, one this source was individual shape files (river, road, urban centers, villages, topography, slope, archaeological sites, gas pipelines, oil pipelines, power lines and railways) which were obtained accordingly using the internal reports of the Iraqi [25]. The second source was available data which was prepared and produced in GIS software (e.g. data for 170 wells of groundwater depths in Babylon Governorate and its surrounding areas were entered into GIS to generate interpolation between these data using the spatial analysis tool called as Kriging [26], and then the spatial analysis tool "Extract by mask" used to produce the raster map of groundwater depth in Babylon Governorate and Al-Mahawil Qadhaa respectively. The third source was produced raster maps drown from published maps. The raster map of "Agricultural land use" was prepared based on the map of land capability of Iraq (scale 1:1000000) [27]. Then it checked on the satellite images of Babylon Governorate dated 2011 [28]. The create the digital map of "soil types" in AlMahawil Qadhaa, the map of exploratory soil of Iraq (scale 1:1,000,000) was used for this purpose [29]. To obtained the locations of industrial areas within this Qadhaa as a digital map, the published map of industrial areas (scale 1:400,000) [23] was used. The digital map of archaeological sites in this Qadhaa was generated based on the relevant information on the archaeological map of Iraq (scale $1: 1,500,000)[30]$.

\subsection{Input Data}

To prepare the rating values of the sub-criteria for each criterion, the raster map of each criterion was divided into categories, and each category was given a suitable rating value based on the opinion of experts, previous studies in this field and various required and available data related to the present study [31] [32] (Table 1). For the "groundwater depths" layer, according to groundwater depth readings, depths of more than 6 , between $4-6 \mathrm{~m}, 2-4 \mathrm{~m}$ and $0-2 \mathrm{~m}$ were given ratings values of $10,6,4$, and 1 respectively (Figure $2(a)$ ). In the "river" layer, in order to reduce the potential for river contamination from landfill, a distance of less than $1000 \mathrm{~m}$ from the boundaries of a river was adopted, and it was assigned zero. A distance of more than $1000 \mathrm{~m}$ was scored as 10 (Figure (b)). The layer of "elevation" was divided into four categories according to the digital elevation model (DEM) of the study area. Elevation areas between $16-22 \mathrm{~m}$ 
Table 1. Description of the sub-criteria buffer zones, the ratings of sub-criteria.

\begin{tabular}{|c|c|c|c|}
\hline No. & Criterion & Buffer Zone & Sub-criteria Ratings \\
\hline \multirow{4}{*}{1} & \multirow{4}{*}{ Groundwater depth (m) } & $0-2$ & 1 \\
\hline & & $2-4$ & 4 \\
\hline & & $4-6$ & 6 \\
\hline & & $>6$ & 10 \\
\hline \multirow{2}{*}{2} & \multirow{2}{*}{ Rivers (km) } & $0-1$ & 0 \\
\hline & & $>1$ & 10 \\
\hline \multirow{3}{*}{3} & \multirow{3}{*}{ Elevation (a.m.s.l.) } & $16-22$ & 3 \\
\hline & & $22-28$ & 5 \\
\hline & & $28-34$ & 7 \\
\hline \multirow{3}{*}{4} & \multirow{3}{*}{ Slope (degree) } & $>34$ & 10 \\
\hline & & $0-5^{\circ}$ & 10 \\
\hline & & Soil 7 (A) & 10 \\
\hline \multirow{5}{*}{5} & \multirow{5}{*}{ Soils types } & Soil 6 (B) & 9 \\
\hline & & Soil 5' (C) & 8 \\
\hline & & Soil 5 (D) & 7 \\
\hline & & Soil $4(\mathrm{E})$ & 6 \\
\hline & & Soil $11(F)$ & 3 \\
\hline \multirow{8}{*}{6} & \multirow{8}{*}{ Land use } & Industrial Area & 0 \\
\hline & & Urban Centers & 0 \\
\hline & & Villages & 0 \\
\hline & & Rivers & 0 \\
\hline & & Archaeological & 0 \\
\hline & & Agricultural lands & 0 \\
\hline & & Orchards & 5 \\
\hline & & Unused lands & 10 \\
\hline \multirow{3}{*}{7} & \multirow{3}{*}{ Agricultural land use } & Agricultural land & 0 \\
\hline & & Orchards & 5 \\
\hline & & Unused land & 10 \\
\hline \multirow{5}{*}{8} & \multirow{5}{*}{ Roads (m) } & $0-500$ & 0 \\
\hline & & $500-1000$ & 7 \\
\hline & & $1000-2000$ & 10 \\
\hline & & $2000-3000$ & 5 \\
\hline & & $>3000$ & 3 \\
\hline \multirow{2}{*}{9} & \multirow{2}{*}{ Railways (m) } & $0-500$ & 0 \\
\hline & & $>500$ & 10 \\
\hline \multirow{4}{*}{10} & \multirow{4}{*}{ Urban centers $(\mathrm{km})$} & $0-5$ & 0 \\
\hline & & $5-10$ & 10 \\
\hline & & $10-15$ & 7 \\
\hline & & $>15$ & 4 \\
\hline \multirow{2}{*}{11} & \multirow{2}{*}{ Villages (m) } & $0-1$ & 0 \\
\hline & & $>1$ & 10 \\
\hline & & $0-1$ & 0 \\
\hline 12 & Archaeological sites $(\mathrm{km})$ & $1-3$ & 5 \\
\hline & & $>3$ & 10 \\
\hline 13 & Gas ninelines $(\mathrm{m})$ & $\leq 300$ & 0 \\
\hline 10 & Gas pipenitics (III) & $>300$ & 10 \\
\hline 14 & Oil pipelines (m) & $\leq 75$ & 0 \\
\hline & & $>75$ & 10 \\
\hline 15 & Power lines $(\mathrm{m})$ & $\leq 30$ & 0 \\
\hline 10 & 10wer intes (III) & $>30$ & 10 \\
\hline
\end{tabular}



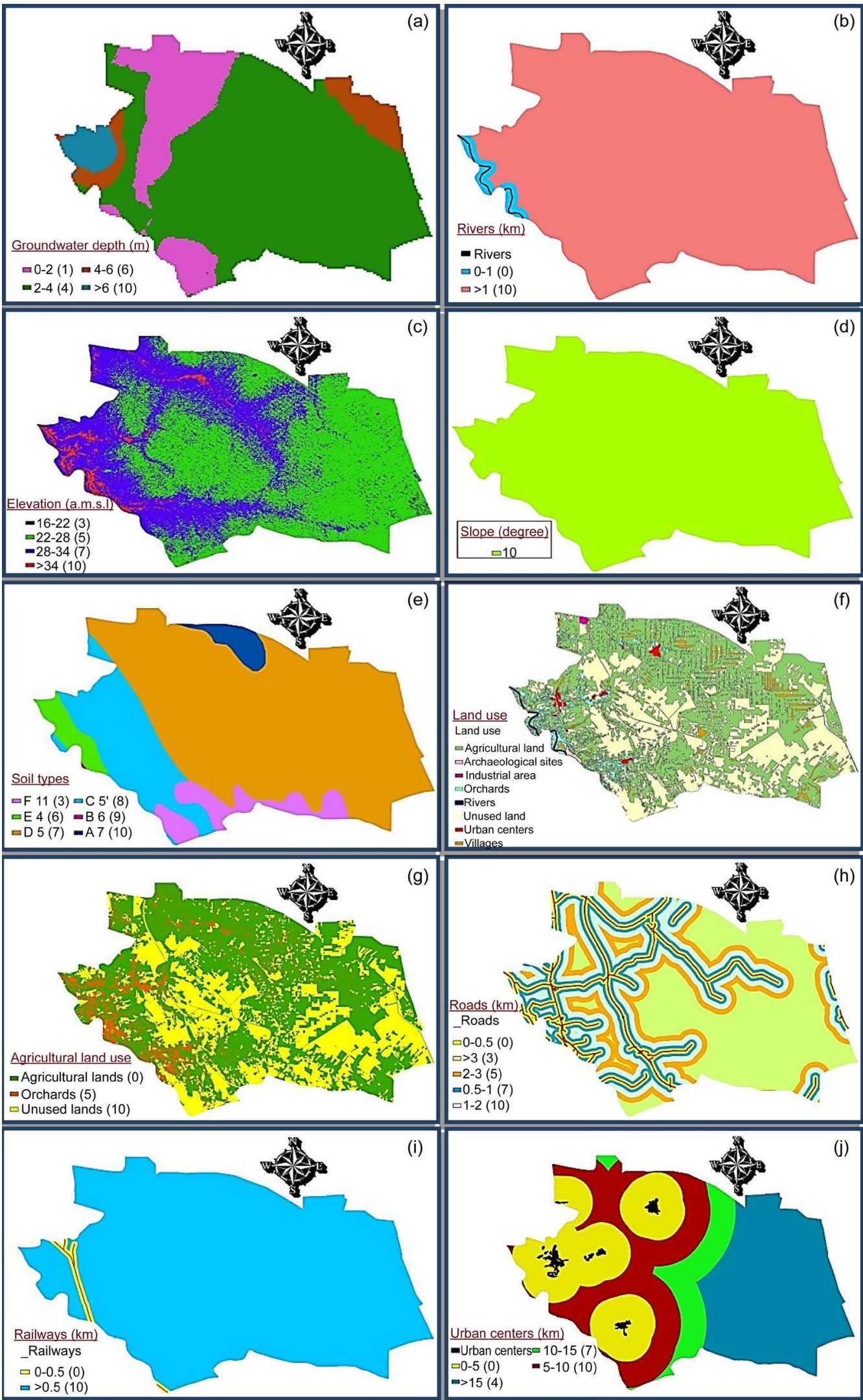

Figure 2. Maps of suitability indexes of (a) Ground water depth, (b) Rivers, (c) Elevation, (d) Slope, (e) Soil types, (f) Land use, (g) Agricultural land use, (h) Roads, (i) Railways, and (j) Urban centers. 
above mean sea level (a.m.s.l.), between 22 - 28 m (a.m.s.l.), between 28 - $34 \mathrm{~m}$ (a.m.s.l.) and greater than $34 \mathrm{~m}$ (a.m.s.l.) were given grading values of 3, 5, 7 and 10 respectively (Figure $2(\mathrm{c})$ ). In Al-Mahawil Qadhaa, all lands have a slope of less than $5^{\circ}$, and they were given a score of 10 (Figure $4(\mathrm{~d})$ ). The layer map of "soil types" in this Qadhaa includes six types of soils according to Buringh (1960) (Figure 2(e)). These soil types are: periodically flooded soils 7 (A), basin depression soils $6(\mathrm{~B})$, river basin soils, poorly drained phase $5(\mathrm{C})$, river basin soils, poorly drained phase 5 (D), river levee soils 4 (E) and active dune land $\mathrm{F}$ (11). After merging all these soil types into a single layer within GIS, they were giving scores of 10, 9, 8, 7, 6 and 3 respectively. The "land use" layer consists of ten categories. These categories are urban centers, villages, industrial areas, archaeological sites, rivers, agricultural land, orchards and unused land. The categories of "orchards" and "unused lands" were assigned scores of 5 and 10 respectively, whereas other categories were given a score of zero (Figure 2(f)). The map layer of "agricultural land use" was divided into three categories. The categories of "agricultural land", "unused land" and "orchards" were given scores of zero, 5, and 10 respectively (Figure $2(\mathrm{~g})$ ). The layer of "roads" comprises main roads and highways. The layer was divided into five categories: buffer zones of greater than $3 \mathrm{~km}$, buffer zones of $2-3 \mathrm{~km}$, buffer zones of $1-2 \mathrm{~km}$, buffer zones of $0.5-1 \mathrm{~km}$ and less than $0.5 \mathrm{~km}$ were given grades of 3, 5, 10, 7 and zero respectively (Figure 2(h)). For the layer of "railway", buffer zones of less than $500 \mathrm{~m}$ on both sides of the railway were given a score of zero. Buffer zones greater than $500 \mathrm{~m}$ were assigned of score of 10 (Figure 2(i)). The map of "urban centers" layer was divided into four categories. Buffer zones of $5-10 \mathrm{~km}$, buffer zones of $10-15 \mathrm{~km}$, buffer zones of more than $15 \mathrm{~km}$ and buffer zones of less than $5 \mathrm{~km}$ were given scores of 10, 7, 4 and zero respectively (Figure 2(j)). For the layer of "villages", buffer zones of less than $1 \mathrm{~km}$ were graded zero, while buffer zones greater than $1 \mathrm{~km}$ were scored 10 (Figure 3(a)). For the "archaeological sites" layer, a buffer zone of less than $1 \mathrm{~km}$, buffer zones of $1-3 \mathrm{~km}$ around these areas, and buffer zones of more than $3 \mathrm{~km}$ were given grading values of zero, 5 and 10 respectively (Figure 3(b)). Buffer zones of more than 300 $\mathrm{m}$ in the "gas pipelines" layer; buffer zones of more than $75 \mathrm{~m}$ in the "oil pipelines" and buffer zones of more than $30 \mathrm{~m}$ in the layer of "power lines" were given scores of 10 . Buffer zones which were less than these values were given a grading value of zero (Figure 4(c), Figure 4(d) and Figure 4(e)).

\subsection{Multi-Criteria Decision Methods}

To produce the criteria weightings for this study, two methods were used: Analytical Hierarchy Process (AHP) and Ratio Scale Weighting. In each method, two different procedures were used to estimate the weightings for criteria, and then these weightings were implemented on their maps' layers within GIS to produce the suitability index map for landfill siting in Al-Mahawil Qadhaa. These methods are given below. 

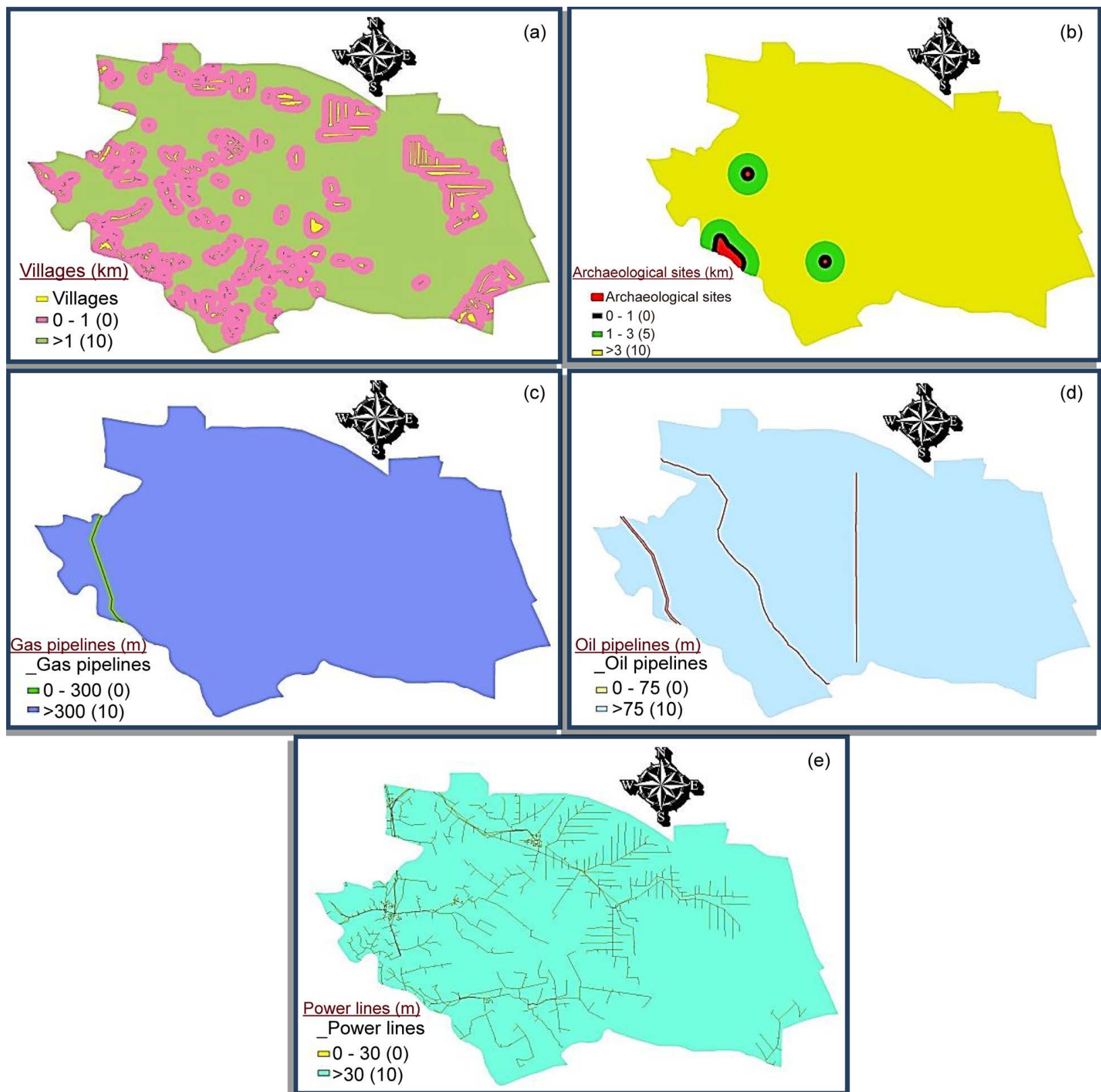

Figure 3. Maps of suitability indexes of (a) Villages, (b) Archaeological sites, (c) Gas pipelines, (d) Oil pipelines and (e) Power lines.

\subsection{Analytical Hierarchy Process (AHP) Method}

The Analytic Hierarchy Process was developed by [10], and it was used to calculate the relative importance of criteria (significant weightings) for the present study through using a pair-wise comparisons matrix. The decision-makers contributed their experience and judgment in the evaluation of the relative importance of each criterion compared to the others, and then in building a pair-wise comparisons matrix using a numerical scale consisting of 9 points. Each point equates to an expression of the relative importance of the two factors.

The eigenvectors $\left(\mathrm{Eg}_{\mathrm{i}}\right)$ were estimated based on multiplying the value for each criterion in each column in the same row in a matrix under the root for numbers 


\begin{tabular}{|c|c|c|c|c|c|c|c|c|c|c|c|c|c|c|c|c|c|}
\hline Criteria & 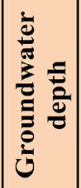 & 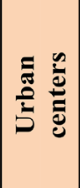 & 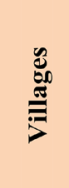 & $\frac{\tilde{D}}{\tilde{a}}$ & & $\frac{\ddot{\partial}}{\sigma}$ & $\begin{array}{l}\tilde{E}_{\tilde{I}} \\
\text { x }\end{array}$ & 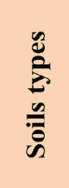 & 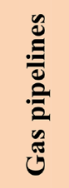 & 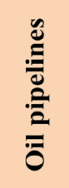 & $\begin{array}{l}\stackrel{\mathscr{E}}{\Xi} \\
\overline{\bar{d}} \\
\tilde{E}\end{array}$ & 疍 & 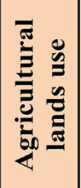 & 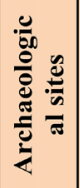 & 葛 & 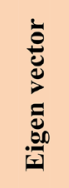 & 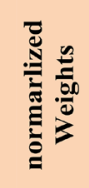 \\
\hline Groundwater depth & 1 & 2 & 3 & 2 & 4 & 5 & 5 & 4 & 8 & 8 & 7 & 6 & 5 & 6 & 9 & 4.33 & 0.2004 \\
\hline Urban centers & 0.50 & 1 & 2 & 1 & 3 & 4 & 4 & 3 & 7 & 7 & 6 & 5 & 4 & 5 & 8 & 3.18 & 0.1471 \\
\hline Villages & 0.33 & 0.50 & 1 & 0.5 & 2 & 3 & 3 & 2 & 6 & 6 & 5 & 4 & 3 & 4 & 7 & 2.24 & 0.1038 \\
\hline Rivers & 0.50 & 1.00 & 2.00 & 1 & 3 & 4 & 4 & 3 & 7 & 7 & 6 & 5 & 4 & 5 & 8 & 3.18 & 0.1471 \\
\hline Elevation & 0.25 & 0.33 & 0.50 & 0.33 & 1 & 2 & 2 & 1 & 5 & 5 & 4 & 3 & 2 & 3 & 6 & 1.53 & 0.0709 \\
\hline Slope & 0.20 & 0.25 & 0.33 & 0.25 & 050 & 1 & 1 & 0.5 & 4 & 4 & 3 & 2 & 1 & 2 & 5 & 1.00 & 0.0463 \\
\hline Roads & 0.20 & 0.25 & 0.33 & 0.25 & 0.50 & 1.00 & 1 & 0.5 & 4 & 4 & 3 & 2 & 1 & 2 & 5 & 1.00 & 0.0463 \\
\hline Soils types & 0.25 & 0.33 & 0.50 & 0.33 & 1.00 & 2.00 & 2.00 & 1 & 5 & 5 & 4 & 3 & 2 & 3 & 6 & 1.53 & 0.0709 \\
\hline Gas pipelines & 0.13 & 0.14 & 0.17 & 0.14 & 0.20 & 0.25 & 0.25 & 0.20 & 1 & 1 & 0.5 & 0.34 & 0.25 & 0.34 & 2 & 0.32 & 0.0146 \\
\hline Oil pipelines & 0.13 & 0.14 & 0.17 & 0.14 & 0.20 & 0.25 & 0.25 & 0.20 & 1.00 & 1 & 0.5 & 0.34 & 0.25 & 0.34 & 2 & 0.32 & 0.0146 \\
\hline Power lines & 0.14 & 0.17 & 0.20 & 0.17 & 0.25 & 0.33 & 0.33 & 0.25 & 2.00 & 2.00 & 1 & 0.5 & 0.34 & 0.5 & 3 & 0.45 & 0.0207 \\
\hline Land use & 0.17 & 0.20 & 0.25 & 0.20 & 0.33 & 0.50 & 0.50 & 0.33 & 2.94 & 2.94 & 2.00 & 1 & 0.5 & 1 & 4 & 0.65 & 0.0302 \\
\hline Agricultural lands use & 0.20 & 0.25 & 0.33 & 0.25 & 0.50 & 1.00 & 1.00 & 0.50 & 4.00 & 4.00 & 2.94 & 2.00 & 1 & 2 & 5 & 1.00 & 0.0462 \\
\hline Archaeological sites & 0.17 & 0.20 & 0.25 & 0.20 & 0.33 & 0.50 & 0.50 & 0.33 & 2.94 & 2.94 & 2.00 & 1.00 & 0.50 & 1 & 4 & 0.65 & 0.0302 \\
\hline Railways & 0.11 & 0.13 & 0.14 & 0.13 & 0.17 & 0.20 & 0.20 & 0.17 & 0.50 & 0.50 & 0.33 & 0.25 & 0.20 & 0.25 & 1 & 0.23 & 0.0107 \\
\hline
\end{tabular}

Figure 4. Pair-wise comparison matrix for landfill siting using AHP, eigenvector and significance weightings.

of elements in this row. This process was applied to each row (Figure 4). The relative weighting for each criterion (priority vector $\left(\mathrm{Pr}_{\mathrm{i}}\right)$ ) was calculated through a normalized eigenvalue for each criterion to 1 by dividing each weight by its sum. The consistency between the relative weightings of criteria obtained from the matrix of pair-wise comparisons was checked by estimating the Consistency Ratio $(\mathrm{CR}=\mathrm{CI} / \mathrm{RI})$, where $\left(\left(\mathrm{CI}=\left(\lambda_{\max }-n / n-1\right)\right)\right.$, and the Consistency Index $\left(\lambda_{\max }\right)$ is obtained from the sum of the products of multiplying the sum of each column of the matrix by the corresponding value of the priority vector, where $n$ is number of criteria. RI is the mean deviation of randomness for matrices with different sizes [10] [33].

In this study, the values of CI $=15.61$, and RI15 $=1.59$. If the Consistency Ratio value is smaller than 0.1 , then the consistency is acceptable. Thus, the CR value was $2.7<0.1$.

\subsection{The Ratio Scale Weighting (RSW) Method}

The decision process in the Ratio Scale Weighting (RSW) method is based on allocating a suitable ratio score value for each criterion, where the value of 100 is given to the most important criterion to be the basis for the values of other criteria. Values smaller than 100 , are proportionally allocated to criteria that are lower in the order according to the importance of each criterion with respect to the others [34]. To estimate the original weightings for criteria $\left(R_{i}\right)$ using the Ratio Scale Weighting (RSW) method, the value of proportional weight of each criterion was divided by the value of proportional weight of the lowest importance criterion. Then, the normalized weights for criteria of the RSW method were estimated using Equation (1) (Table 2).

$$
W_{i}=\frac{R_{i}}{\sum_{j=1}^{n} R_{j}} i=1,2, \cdots, n
$$


Table 2. The criterion weightings defined for the Ratio Scale Weighting (RSW) method.

\begin{tabular}{ccccc}
\hline No. & Criteria & Ratio scale value & Original weight $\left(R_{i}\right)$ & Normalized weight $\left(W_{i}\right)$ \\
\hline 1 & Groundwater depth & 100 & 20 & 0.2012 \\
2 & Urban centers & 74 & 14.8 & 0.1489 \\
3 & Rivers & 73 & 14.6 & 0.1469 \\
4 & Villages & 52 & 10.4 & 0.1046 \\
5 & Elevation & 35 & 7 & 0.0704 \\
6 & Soils types & 35 & 7 & 0.0704 \\
7 & Slope & 23 & 4.6 & 0.0463 \\
8 & Roads & 23 & 4.6 & 0.0463 \\
9 & Agricultural land use & 23 & 4.6 & 0.0463 \\
10 & Land use & 15 & 3 & 0.0302 \\
11 & Archaeological sites & 15 & 3 & 0.0302 \\
12 & Power lines & 10 & 2 & 0.0201 \\
13 & Gas pipelines & 7 & 1.4 & 0.0141 \\
14 & Oil pipelines & 7 & 1.4 & 0.0141 \\
15 & Railways & 5 & 1 & 0.0100 \\
& Sum & & 99.4 & 1 \\
\hline
\end{tabular}

where:

$W_{i}$ is the normalized weight of each criterion which was divided by the Original weight of each criterion by their sum; $R_{i}$ : the Original weight of each criterion of area $i$ under criterion $\mathrm{j}$; $\mathrm{n}$ : number of criteria.

\subsection{Analysis Process Methods}

To obtain the final maps of suitability index for landfill siting, overlaying analysis was performed on the layers maps of criteria, which were entered within GIS. The method of Weighted Linear Combination (WLC) was applied on all criteria using the spatial analysis tool "Map Algebra". This method was used based on the following Equation (2):

$$
A_{i}=\sum_{j=1}^{n} W_{j} \times C_{i j}
$$

where:

$A_{i}$ is the suitability index for area $i, W_{j}$ is the relative importance weighting of the criterion, $C_{i j}$ is the grading value of area $i$ under criterion $j$, and $n$ is the total number of criteria [35] [36].

In summary, the suitability index was calculated for each final map of the AHP and the RSW methods through the sum of the products of multiplying the rating values of the sub-criteria for each criterion (based on the opinion of experts in this field) (Table 1) by the weight of each criterion which was calculated using the AHP and RSW methods (Table 3). 
Table 3. The values of criteria's weightings which were estimated from the AHP and RSW methods.

\begin{tabular}{cccc}
\hline No. & Criterion & Criterion's weight (AHP) & Criterion's weight (RSW) \\
\hline 1 & Groundwater depth (m) & 0.2004 & 0.2012 \\
2 & Rivers (km) & 0.1471 & 0.1469 \\
3 & Elevation (a.m.s.l.) & 0.0709 & 0.0704 \\
4 & Slope (degree) & 0.0463 & 0.0463 \\
5 & Soils types & 0.0709 & 0.0704 \\
6 & Land use & 0.0302 & 0.0302 \\
7 & Agricultural land use & 0.0462 & 0.0463 \\
8 & Roads (m) & 0.0463 & 0.0463 \\
9 & Railways (m) & 0.0107 & 0.01 \\
10 & Urban centers (km) & 0.1471 & 0.1489 \\
11 & Villages (m) & 0.1038 & 0.1046 \\
12 & Archaeological sites (km) & 0.0302 & 0.0302 \\
13 & Gas pipelines (m) & 0.0146 & 0.0141 \\
14 & Oil pipelines (m) & 0.0146 & 0.0141 \\
15 & Power lines (m) & 0.0207 & 0.0201 \\
\hline & & &
\end{tabular}

The suitability index maps for landfill siting in Al-Mahawil Qadhaa were produced using the AHP, RSW and WLC methods. Each map was divided into four categories. The four categories with their areas and also their proportion in the AHP method are as follows: "unsuitable", $27.923(1.48 \%) \mathrm{km}^{2}$; "moderately suitable", 414.667 (21.9\%) km²; "suitable", 1070.55 (56.56\%) km²; and "most suitable" 379.749 (20.06\%) km² (Figure 5(a)).

In the Ratio Scale Weighting (RSW) method, the area of each category with their proportions is as follows: "unsuitable", $29.854(1.58 \%) \mathrm{km}^{2}$; "moderately suitable", $413.684(21.85 \%) \mathrm{km}^{2}$; "suitable", $1070.64(56.56 \%) \mathrm{km}^{2}$; and "most suitable", 378.715 (20.01\%) km² (Figure 5(b)).

\subsubsection{Combination of Maps}

In order to combine the maps that resulted from the two methods (AHP and RSW), each map was classified into four categories and the same range was used for each map and each category. The four categories were: unsuitable, moderately suitable, suitable and most suitable (Figure 6). Each category within maps has a number of pixels and, consequently, this help in the combination process. In order to combine two maps, the raster maps were entered into GIS, and the special analysis tool 'Local' and then 'Combine' were used. The resultant databases were exported to an Excel file. To create the matrix of data which will be used in estimating the error matrix of accuracy assessment methods (Kappa and Overall Assessment) between the two maps, the special analysis tools "Data Management Tools", "Table" and "Pivot Table" were used, and then the file was saved as a dBase type file. 


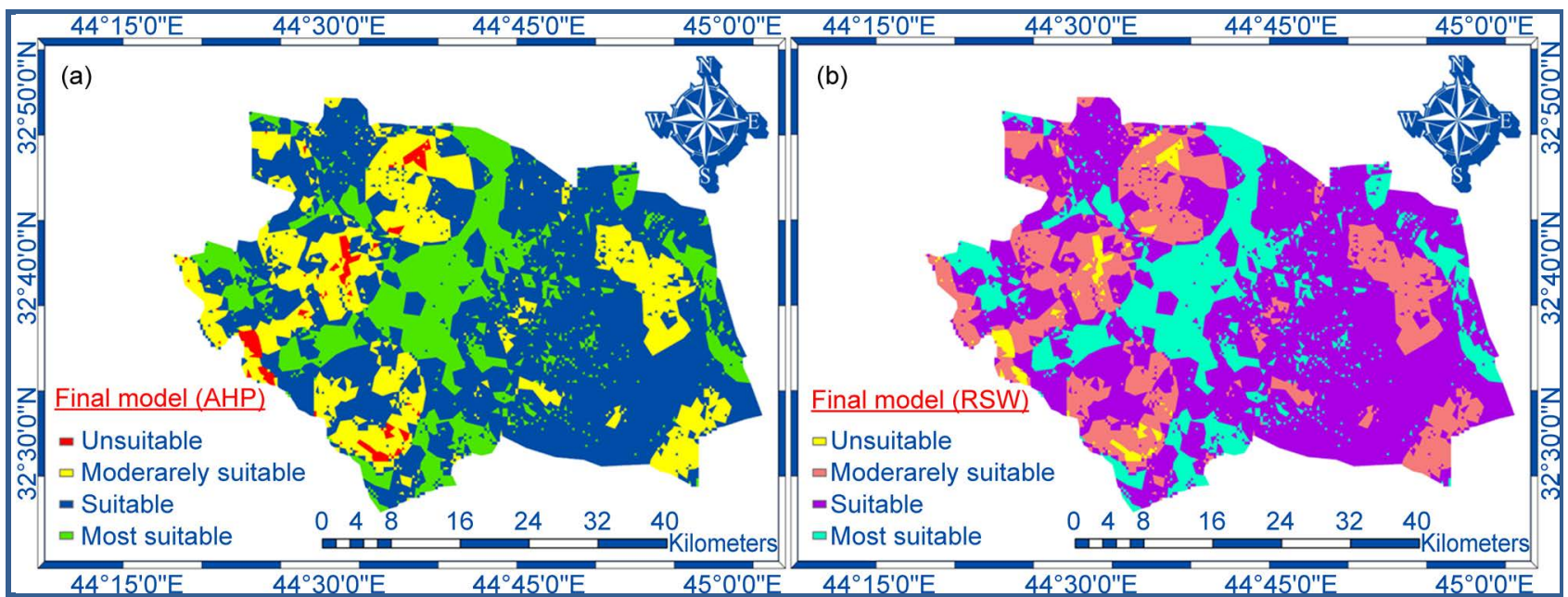

Figure 5. Final maps of suitability index for landfill sitting using (a) AHP method and (b) the RSW method.

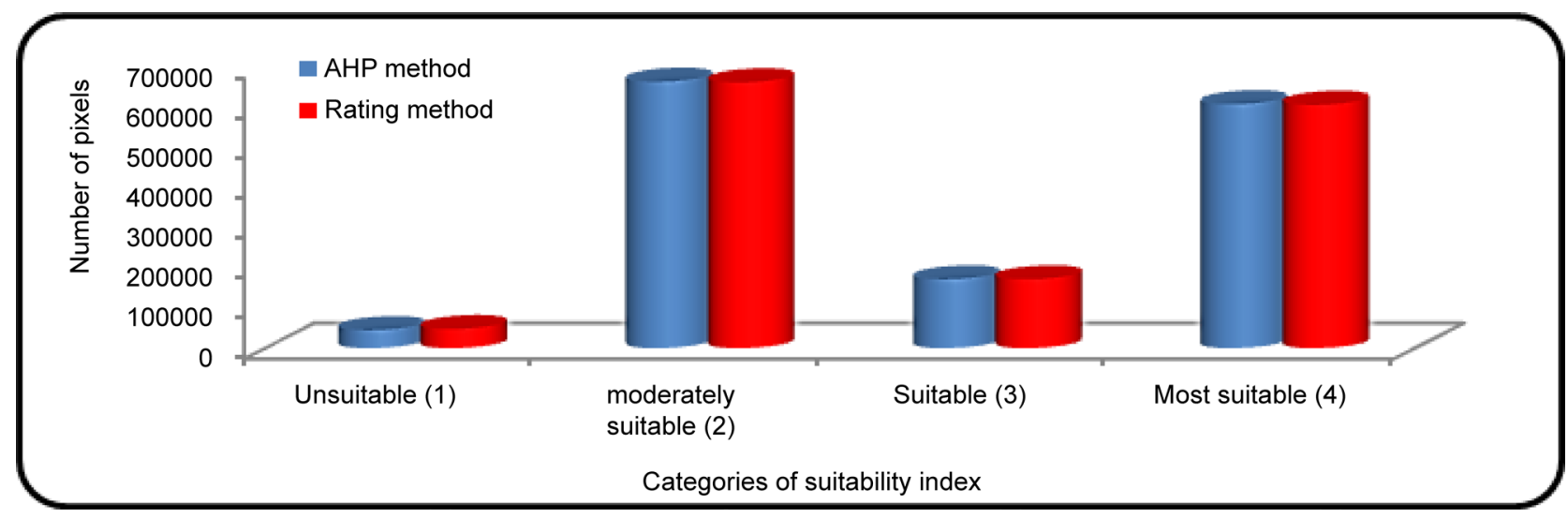

Figure 6. Categories of suitability index and number of pixels resulting from the two maps.

\subsubsection{Accuracy Assessment Methods (Kappa Overall Assessment)}

The Kappa technique was introduced by [22], and it is used to estimate the agreement between a raster map of a prediction model and a raster map which has real geographic features in special locations using the error or correlation or covariance matrix [37]. In this study, The Kappa technique was used to measure the relationship between the databases of similar categories (four categories) for two output images maps which were produced using the AHP and RSW methods using a correlation matrix. After combining the four categories of the two raster maps within GIS, and then importing the data into an Excel file. The correlation matrix was created and imported its data into excel file (Table 4).

The Kappa technique was used to measure the association or agreement between the output images resulting from the different analysis methods that produced the AHP raster map, which is considered an essential map for comparison, and the RSW raster map, using the correlation matrix. Cohen's Kappa is computed as follows [38].

$$
K=\frac{N \sum_{i=1}^{r} X_{i i}-\sum_{i=1}^{r}\left(X_{i+} \times X_{+i}\right)}{N^{2}-\sum_{i=1}^{r}\left(X_{i+} \times X_{+i}\right)}
$$


Table 4. The correlation matrix resulting from combining the final maps from the AHP and RSW methods.

\begin{tabular}{|c|c|c|c|c|c|}
\hline Category & RSW-1 & RSW-2 & RSW-3 & RSW-4 & Sum \\
\hline AHP-1 & 44,682 & 3016 & 65 & 0 & 47,763 \\
\hline AHP-2 & 0 & 659,794 & 2051 & 60 & 661,905 \\
\hline AHP-3 & 0 & 679 & $1,709,979$ & 2564 & $1,713,222$ \\
\hline \multirow[t]{2}{*}{ AHP-4 } & 0 & 0 & 998 & 604,843 & 605,841 \\
\hline & 44,682 & 663,489 & $1,713,093$ & 607,467 & $3,028,731$ \\
\hline
\end{tabular}

where:

$N$ : total number of cells in the error matrix, $r$. number of rows in the matrix, $X_{i i}$ total number in row $i$ and in column $i, X_{+i}$ the total for row i, $X_{i+}$ : the total for column $i$.

The value of Kappa for the correlation matrix was estimated based on (Table 2) using Equation (3), as follows:

$$
\begin{gathered}
N=3,028,731, N_{2}=9.17321 \mathrm{E}+12, X_{i i}=(44,682+65,9794+1,709,979+ \\
604,843)=3,019,298,\left(X_{+i} \times X_{i+}\right)=((47,763 \times 44,682)+(661,905 \times 663,489)+
\end{gathered}
$$$$
(1,713,222 \times 1,713,093)+(605,841 \times 607,467)=3.74424 \mathrm{E}+12
$$

$$
K=\frac{(3,028,731 \times 3,019,298)-(3.74424 \mathrm{E}+12)}{(9.17321 \mathrm{E}+12-3.74424 \mathrm{E}+12)}=99.474
$$

The Cohen's Kappa value between the categories of the two maps obtained from the AHP and the RSW methods was equal to $99.474 \%$, and it was considered a high level of agreement according to [39]. The error value of the correlation matrix was $0.526 \%$.

In order to calculate the accuracy of the overall assessment value (OA) between the two maps from the AHP and RSW methods, the summation values of cell numbers along the major diagonal (DV) was divided by the total value of cells in the correlation matrix (TV). The accuracy of Overall Assessment is estimated as follows.

$$
\mathrm{OA}=\frac{\mathrm{DV}}{\mathrm{TV}} \times 100
$$

where:

OA: The overall assessment value that was resulted from comparison between the two maps using the AHP and RSW methods, DV: the summation values of cell numbers along the major diagonal for the matrix, TV: the total value that resulted from summation the values of cells in the correlation matrix.

The overall assessment value for the matrix of correlation was computed using Equation (4) based on (Table 2), as follows:

$$
\mathrm{OA}=\frac{(44,682+659,794+1,709,979+604,843)}{3,028,731} \times 100 \%=99.689 \%
$$

In this study, through using two methods (Kappa and Overall Assessment) to assess the accuracy of correlation between two raster maps produced using the 
AHP and the RSW methods using a correlation matrix, the resulting values of the accuracy assessment methods were very similar to each other. The overall Assessment value for all cells which was resulted from comparison between two image maps was approximately $99.689 \%$, indicating a strong statistical correspondence to the kappa percentage $99.474 \%$.Thus, the Kappa technique is considered a very quick and significant method for a comparison between two maps resulting from using two prediction models.

Figure 7 shows the percentage of raster values for the matching and nonmatching classes. The percentages of matching pixels in the combination map are $99.479 \%$ (in blue), while the percentage of the non-matching pixels is $0.521 \%$ (yellow) using the Kappa technique.

\section{Results and Discussion}

After determining the weighting for each criterion using two methods (AHP and RSW) and the rating weightings for the sub-criteria of each criterion, the method of Weighted Linear Combination (WLC) was applied to all criteria using the spatial analysis tool "Map Algebra" within GIS to produce the final output maps for the suitability index for landfill siting. The result of this process produced two final output maps of the suitability index of candidate sites for landfill. Then, the two final raster maps which resulted from using AHP and Ratio Scale Weighting methods were combined.

In Al-Mahawil Qadhaa, the cumulative quantity of solid waste expected in 2030 and from 2020 to 2030 is 96,389 tonnes and 877,419 tonnes respectively, as calculated by [6]. The expected population in this Qadhaa in 2030 is 618,274

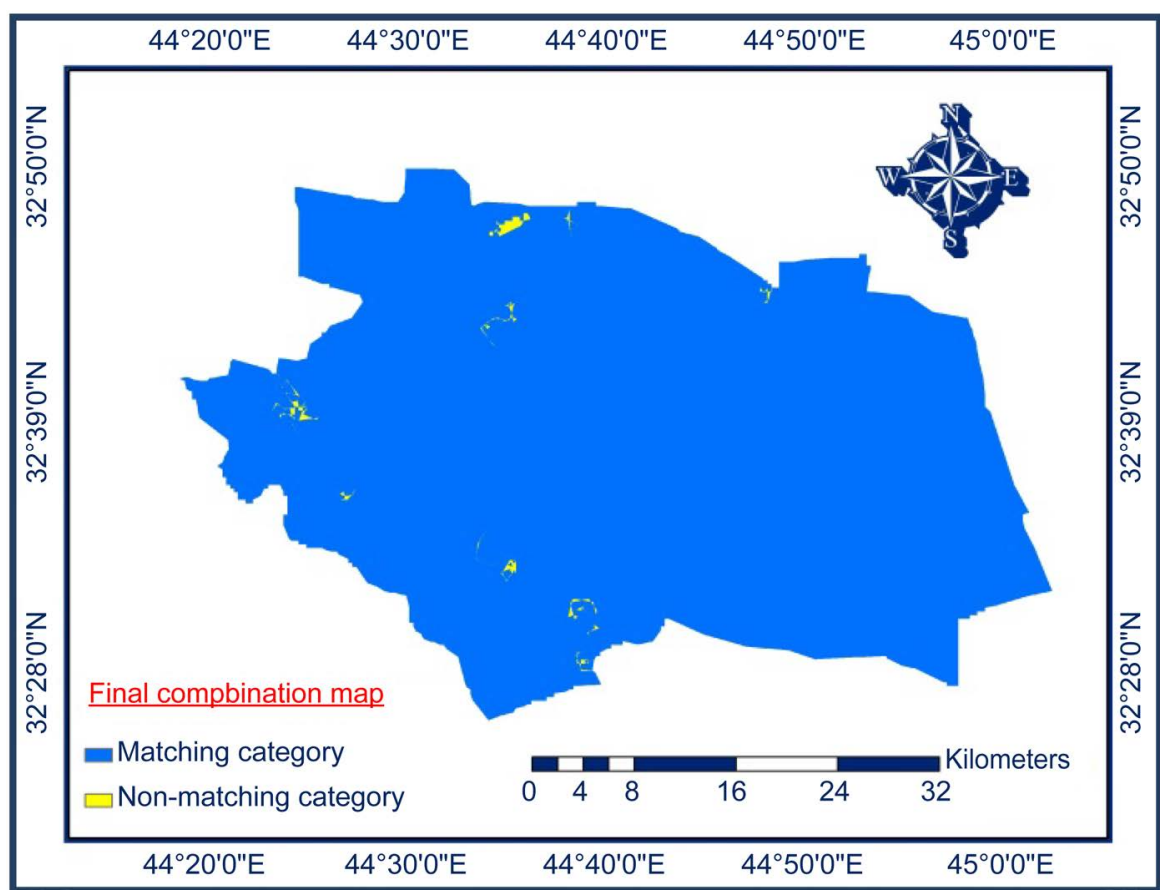

Figure 7. The combination map of matching and non-matching areas between (AHP and RSW) methods and its percentages. 
inhabitants calculated according to the present population growth rate. The waste density in the waste disposal sites is $450 \mathrm{~kg} / \mathrm{m}^{3}$ in Al-Mahawil Qadhaa according to the [40]. Thus, the volume of waste and cumulative waste are $214,198 \mathrm{~m}^{3}$ and $1,949,820 \mathrm{~m}^{3}$ respectively. The average suggested depth to the groundwater in the candidate sites that resulted from this study was adopted as $2 \mathrm{~m}$ because the groundwater depth from the ground surface in Al-Mahawil Qadhaa is shallow. According to these requirements, the area of the candidate site required to accommodate the cumulative quantity of solid waste generated from 2020 to 2030 was found to be $0.975 \mathrm{~km}^{2}$.

Two candidate sites were selected for landfill among the many sites which resulted from this study (Figure 8). The areas of site No. 1 and 2 are $2218 \mathrm{~km}^{2}$ and $2950 \mathrm{~km}^{2}$ respectively. The two sites were checked on the satellite images (2011) from the Babylon Governorate to make sure that these sites are suitable for landfill, with site No. 1 situated at latitude $32^{\circ} 38^{\prime} 12^{\prime \prime} \mathrm{N}$, and longitude $44^{\circ} 34^{\prime} 9^{\prime \prime} \mathrm{E}$, and site. No. 2 situated at latitude $32^{\circ} 29^{\prime} 59^{\prime \prime} \mathrm{N}$, and longitude $44^{\circ} 41^{\prime} 2 \mathrm{E}$.

\section{Conclusions}

This study used the integration of GIS and methods of multi-criteria decision making (AHP and RSW) and through adopting the scientific and environmental criteria that are followed in developed countries in order to select suitable sites for landfill in Al-Mahawil Qadhaa. The process of an overlaying analysis of fifteen layers of raster maps was implemented within the GIS environment in order to solve the problem of landfill siting in this Qadhaa. The layers maps were groundwater depth, rivers, elevation, slope, soil types, land use, agricultural land use, roads, railways, urban centers, villages, archaeological sites, gas pipelines, oil

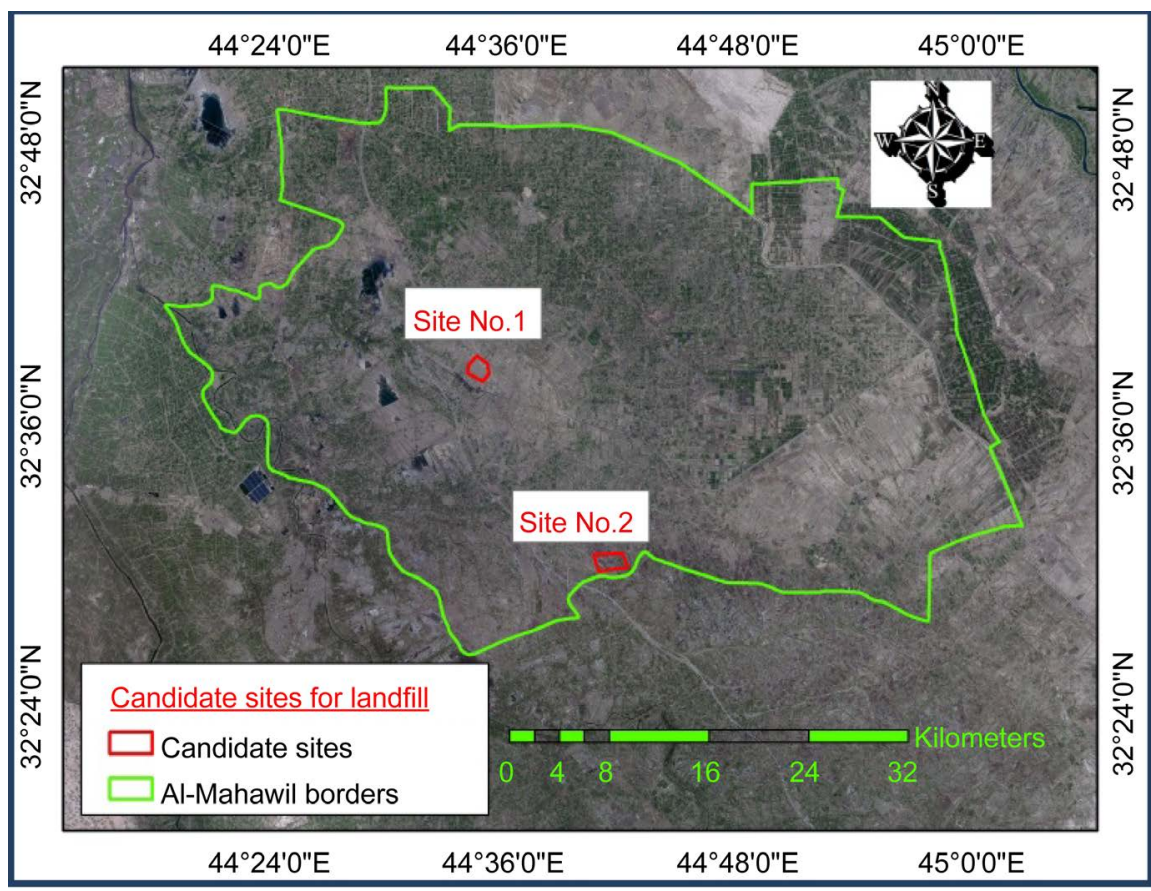

Figure 8. The candidate sites in Al-Mahawil Qadhaa. 
pipelines and power lines. The two methods of multi-criteria decision making were used to identify the weightings for criteria in different styles. The first method was the AHP, which used a matrix of sequences of pair-wise comparisons between criteria to derive the weighting for each criterion. The Ratio Scale Weighting (RSW) method was the second method, based on the opinion of experts through allocating proper ratio values for the criteria in terms of relative importance.

The weighted linear combination (WLC) method was used to produce the final suitability index map for landfill in the study area using the spatial analysis tool "Map Algebra". This procedure was done through summation of the products of multiplying the criteria weightings with the weighting of each sub-criteria of each criterion. After combining the two final maps which resulted from the AHP and RSW methods within GIS, accuracy assessment methods were used to measure an agreement between the output maps for these methods through creating a correlation matrix. The overall Assessment method was used to compare between all pixels for all categories of the two maps produced using the AHP and RSW methods, whilst the Kappa technique was a strong, accuracy and statistical significance method using to measure the agreement between the pixels of two maps using the AHP and RSW methods. Thus, the percentages of accuracy between found by using the Kappa and Overall Assessment (OA) methods were $99.474 \%$, and $99.689 \%$ respectively.

For selecting suitable locations for landfill in Al-Mahawil Qadhaa, two candidate sites were considered. The satellite image of the Babylon Governorate in 2011 was used to ensure that these sites were adequate for landfill.

\section{Acknowledgements}

This work was carried out at Lulea University of Technology, Lulea, Sweden, and Iraqi Ministry of Higher Education.

\section{References}

[1] Luis, F. and Bakken, D.P. (2005) Solid Waste Management. United Nations Environment Programme (UNEP), 72 p.

[2] Moeinaddini, M., Khorasani, N., Danehkar, A., Darvishsefat, A.A. and Zienalyan, M. (2010) Siting MSW Landfill Using Weighted Linear Combination and Analytical Hierarchy Process (AHP) Methodology in GIS Environment (Case Study: Karaj). Waste Management, 30, 912-920. https://doi.org/10.1016/j.wasman.2010.01.015

[3] Brockerhoff, M.P. (2000) An Urbanizing World. Population Reference Bureau (PRB), $55,1-48$.

[4] Proske, H., Vlcko, J., Rosenbaum, M.S., Dorn, M., Culshaw, M. and Marker, B. (2005) Special Purpose Mapping for Waste Disposal Sites. Bulletin of Engineering Geology and the Environment, 64, 1-54. https://doi.org/10.1007/s10064-004-0261-6

[5] Lin, H. and Kao, J. (1999) Enhanced Spatial Model for Landfill Siting Analysis. Journal of Environmental Engineering, 125, 845-951. https://doi.org/10.1061/(ASCE)0733-9372(1999)125:9(845)

[6] Chabuk, A., Al-Ansari, N., Hussain, H.M., Knutsson, S. and Pusch, R. (2015) Present 
Status of Solid Waste Management at Babylon Governorate, Iraq. Engineering, 7, 408-423. https://doi.org/10.4236/eng.2015.77037

[7] Kontos, T.D., Komilis, D.P. and Halvadakis, C.P. (2003) Siting MSW Landfills on Lesvos Island with a GIS Based Methodology. Waste Management \& Research, 21, 262-277. https://doi.org/10.1177/0734242X0302100310

[8] Nas, B., Cay, T., Iscan, F. and Berktay, A. (2010) Selection of MSW Landfill Site for Konya, Turkey Using GIS and Multi-Criteria Evaluation. Environmental Monitoring and Assessment, 160, 491-500. https://doi.org/10.1007/s10661-008-0713-8

[9] Şener, Ş., Şener, E. and Karagüzel, R. (2011) Solid Waste Disposal Site Selection with GIS and AHP Methodology: A Case Study in Senirkent-Uluborlu (Isparta) Basin, Turkey. Environmental Monitoring and Assessment, 173, 533-554. https://doi.org/10.1007/s10661-010-1403-x

[10] Saaty, T.L. (1980) The Analytic Hierarchy Process. McGraw Hill, New York.

[11] Saaty, T.L. (2000) Fundamentals of Decision Making and Priority Theory with AHP. RWS Publications, Pittsburg.

[12] Siddiqui, M.Z., Everett, J.W. and Vieux, B.E. (1996) Landfill Siting Using Geographic Information Systems: A Demonstration. Journal of Environmental Engineering, 122, 515-523. https://doi.org/10.1061/(ASCE)0733-9372(1996)122:6(515)

[13] Şener, B., Suzen, L.M. and Doyuran, V. (2006) Landfill Site Selection by Using Geographic Information Systems. Journal of Environ Geology, 49, 376-388. https://doi.org/10.1007/s00254-005-0075-2

[14] Kara, C. and Doratli, N. (2012) Application of GIS/AHP in Siting Sanitary Landfill: A Case Study in Northern Cyprus. Journal of Waste Management \& Research, 30, 966-980. https://doi.org/10.1177/0734242X12453975

[15] Ghobadi, M.H., Babazadeh, R. and Bagheri, V. (2013) Siting MSW Landfills by Combining AHP with GIS in Hamedan Province, Western Iran. Journal of Environmental Earth Science, 70, 1823-1840. https://doi.org/10.1007/s12665-013-2271-9

[16] Shahabi, H., Keihanfard, S., Ahmad, B.B. and Amiri, M.J. (2014) Evaluating Boolean, AHP and WLC Methods for the Selection of Waste Landfill Sites Using GIS and Satellite Image. Journal of Environmental Earth Science, 71, 4221-4233. https://doi.org/10.1007/s12665-013-2816-y

[17] Yıldırım, Ü. and Güler, C. (2016) Identification of Suitable Future Municipal Solid Waste Disposal Sites for the Metropolitan Mersin (SE Turkey) Using AHP and GIS Techniques. Journal of Environmental Earth Science, 75, 101. https://doi.org/10.1007/s12665-015-4948-8

[18] Uyan, M. (2014) MSW Landfill Site Selection by Combining AHP with GIS for Konya, Turkey. Journal of Environmental Earth Science, 71, 1629-1639. https://doi.org/10.1007/s12665-013-2567-9

[19] Halvadakis, C.P. (1993) Municipal Solid Waste Landfill Siting in Greece-The Case of the Greater Haniaregion, Crete. Journal of Ekistics, 358-359, 45-52.

[20] Sadek, S., El-Fadel, M. and Freiha, F. (2006) Compliance Factors within a GIS-Based Framework for Landfill Siting. International Journal of Environmental Studies, 63, 71-86. https://doi.org/10.1080/00207230600562213

[21] Delgado, O.B., Mendoza, M., Granados, E.L. and Geneletti, D. (2008) Analysis of Land Suitability for the Siting of Inter-Municipal Landfills in the Cuitzeo Lake Basin, Mexico. Journal of Waste Management, 28, 1137-1146. https://doi.org/10.1016/j.wasman.2007.07.002

[22] Cohen, J.A. (1960) Coefficient of Agreement for Nominal Scales. Journal of Educational and Psychological Measurement, 20, 37-46. 
https://doi.org/10.1177/001316446002000104

[23] Iraqi Ministry of Municipalities and Public Works (2009) Structural Plan of Babylon Governorate. The Directorate General of Urban Planning, Information Analysis Report, 2nd Edition, 223.

[24] Iraqi Ministry of Planning (2015) Records of Directorate of Census Babylon. Internal Reports, Iraqi Ministry of Planning, Baghdad.

[25] Iraqi Ministry of Education (2015) Data of the Directorate General. Internal Reports, The Department of Scientific Affairs, Baghdad.

[26] Iraqi Ministry of Water Resources (2015) General Commission for Groundwater. Internal Reports, Iraqi Ministry of Water Resources, Baghdad.

[27] Iraqi Ministry of Water Resources (1990) State commission of survey. Internal Reports, Iraqi Ministry of Water Resources, Baghdad.

[28] Iraqi Ministry of Municipalities and Public Works (2011) Directorate of Sewage Babylon. Internal Reports, Iraqi Ministry of Municipalities and Public Works, Baghdad.

[29] Buringh, P. (1960) Soils and Soil Conditions in Iraq. The Ministry of Agriculture, Baghdad, 337 p.

[30] World Digital Library (2013) The Archaeological Map of Iraq. http://www.wdl.org/en/item/212/

[31] Chabuk, A., Al-Ansari, N., Hussain, H.M., Knutsson, S. and Pusch, R. (2016) Landfill Site Selection Using Geographic Information System and Analytical Hierarchy Process: A Case Study Al-Hillah Qadhaa, Babylon, Iraq. Journal of Waste Management \& Research, 34, 427-437. https://doi.org/10.1177/0734242X16633778

[32] Chabuk, A., Al-Ansari, N., Hussain, H.M., Knutsson, S. and Pusch, R. (2016) Landfill Siting Using GIS and AHP (Analytical Hierarchy Process): A Case Study Al-Qasim Qadhaa, Babylon, Iraq. Journal of Civil Engineering and Architecture, 10, 530-543.

[33] Chang, C., Wu, C., Lin, C. and Lin, H. (2007) Evaluating Digital Video Recorder Systems Using Analytic Hierarchy and Analytic Network Processes. Information Sciences, 177, 3383-3396. https://doi.org/10.1016/j.ins.2007.02.010

[34] Şener, B. (2004) Landfill Site Selection by Using Geography Information System. MSc Dissertation, Middle East Technical University, Ankara.

[35] Gemitzi, A., Tsihrintzis, V.A., Voudrias, E., Petalas, C. and Stravodimos, G. (2007) Combining Geographic Information System, Multicriteria Evaluation Techniques and Fuzzy Logic in Siting MSW Landfills. Journal of Environmental Geology, 51, 797-811. https://doi.org/10.1007/s00254-006-0359-1

[36] El-Alfy, Z., Elhadary, R. and Elashry, A. (2010) Integrating GIS and MCDM to Deal with Landfill Site Selection. International Journal of Engineering \& Technology, 10, $32-42$.

[37] Congalton, R.G. (1991) A Review of Assessing the Accuracy of Classifications of Remotely Sensed Data. Journal of Remote Sensing of Environment, 37, 35-46. https://doi.org/10.1016/0034-4257(91)90048-B

[38] University of Alberta, Biological Sciences-GIS (2004) Error Matrix for Map Comparison or Accuracy Assessment. http://www.biology.ualberta.ca/facilities/GIS/uploads/instructions/AVErrorMatrix. pdf

[39] Landis, J.R. and Koch, G.G. (1977) The Measurement of Observer Agreement for Categorical Data. Journal of Biometrics, 33, 159-174.

https://doi.org/10.2307/2529310 
[40] Iraqi Ministry of Municipalities and Public Works (2015) Records of Directorate of Babylon Municipalities, Babylon. Internal Reports, Iraqi Ministry of Municipalities and Public Works, Baghdad.

Submit or recommend next manuscript to SCIRP and we will provide best service for you:

Accepting pre-submission inquiries through Email, Facebook, LinkedIn, Twitter, etc. A wide selection of journals (inclusive of 9 subjects, more than 200 journals)

Providing 24-hour high-quality service

User-friendly online submission system

Fair and swift peer-review system

Efficient typesetting and proofreading procedure

Display of the result of downloads and visits, as well as the number of cited articles

Maximum dissemination of your research work

Submit your manuscript at: http://papersubmission.scirp.org/

Or contact eng@scirp.org 